\title{
$\nabla$ \\ Cutaneous neonatal herpes simplex virus infection type 2: a case report ${ }^{*}$
}

\author{
Maraya de Jesus Semblano Bittencourt ${ }^{1}$ \\ Marion Guimarães Drago ${ }^{1}$ \\ Bianca Angelina Macêdo do Nascimento ${ }^{1}$
}

Lívia Karlla Marinho Freitas ${ }^{1}$

Alessandra Haber Carvalho ${ }^{1}$

DOI: http:/ / dx.doi.org/10.1590/abd1806-4841.20163870

\begin{abstract}
Neonatal herpes is a serious condition. Newborns can be contaminated in utero via transplacental hematogenic transmission, upon delivery (the most frequent route), or during the postnatal period (indirect transmission). Optimal management requires prompt and accurate recognition, particularly in newborns, in order to prevent complications. Acyclovir is the treatment of choice, but its implementation is often delayed while awaiting test results, such as PCR and serology. Cytology for diagnostic purposes is rarely used in dermatology, despite the quick and reliable results. We report a case of neonatal herpes caused by type 2 herpes simplex virus diagnosed by cytology.
\end{abstract}

Keywords: Herpes simplex; Newborn; Skin

\section{INTRODUCTION}

Neonatal blistering eruptions include a group of disorders that present a wide range of differential diagnoses. Dermatologists must be able to recognize these cutaneous medical conditions and, above all, know how to differentiate them from other serious and potentially fatal dermatoses. ${ }^{1}$ In most cases, neonatal vesicular eruptions can be identified clinically or through simple laboratory procedures. Neonatal infections by herpes simplex virus (HSV), though relatively rare, are associated with significant mortality if not recognized and treated quickly. The present study reports a case of neonatal herpes caused by herpes simplex virus type 2 (HSV 2), diagnosed on the sixth day of life by a cytological exam.

\section{CASE REPORT}

A male newborn (NB), born at 36 weeks of life by normal vaginal delivery, birth weight $2,134 \mathrm{~g}$. The Apgar scores were 10 and 10 at 1 and 5 minutes, respectively. His mother had no history of genital herpes simples during pregnancy or at the time of delivery. Pregnancy was uneventful and general physical exam of the NB at birth was unremarkable.
Shortly after birth, the mother noted the appearance of a "red spot" on his neck, which rapidly extended to his face, anterior thorax, and right arm. Twenty-six hours after birth, crops of vesicles developed on the erythematous areas resulting, later on, in exulceration and crusts. , Intravenous (IV) oxacillin was started, with no improvement after five days of treatment. He showed no fever or other complications during this period.

On his sixth day of life, the NB was referred for dermatological evaluation and erythematous plaques topped with multiple, grouped vesicles in herpetiform pattern, exulceration and crusts were detected in the face, neck, anterior trunk, and right upper limb (Figure 1). The cytology exam, stained by Giemsa, performed at bedside, revealed the presence of enlarged, multinucleated keratinocytes (Figure 2).

IgG and IgM against HSV-2 was positive on the tenth day of life. The patient was treated with IV acyclovir $(30 \mathrm{mg} / \mathrm{kg} /$ day) with complete resolution within ten days (Figure 3). Chest x-ray, abdominal ultrasound, ophthalmological and routine laboratory exams were normal.

\footnotetext{
Received on 22.07.2014

Approved by the Advisory Board and accepted for publication on 13.10.2014

Work conducted in the Dermatology Service of the Federal University of Pará (UFPA), Belém, PA, Brazil.

Financial Support: None.

Conflict of Interest: None.

1 Universidade Federal do Pará (UFPA) - Belém (PA), Brazil.
}

(C2016 by Anais Brasileiros de Dermatologia 

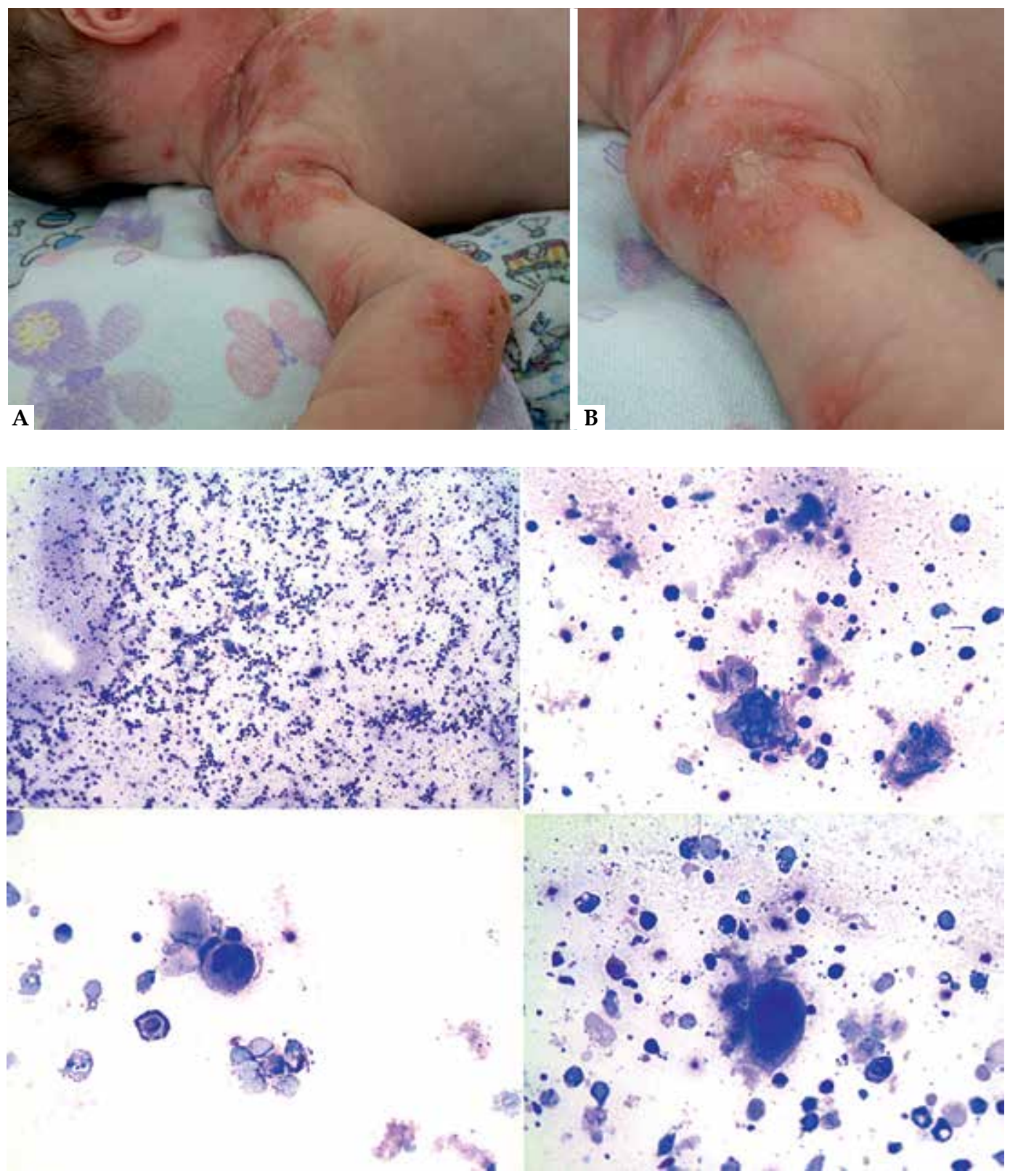

Figure 1:

A: $\quad$ Erythematous plaques presenting vesicle areas grouped in herpetiform, ulceration, and scab patterns, distributed throughout the regions of the face, neck, anterior thorax, and right upper limb. B: Detail of the vesicles submitted to the cytological exam
Figure 2:

Cytological exam stained by Giemsa, showing the presence of a large volume of multinucleated keratinocytes

\section{DISCUSSION}

HSV is a common pathogen, causing a broad spectrum of diseases that range from minor skin infections to severe encephalitis and widespread infections. $^{2}$ This virus can infect different types of cells. The infection of neural tissue results in the destruction of neurons and glial cells, while the damage of epithelial tissues leads to the formation of high virus content vesicles, which can be transmitted to another individual by close contact.

Most of the affected NBs acquire the infection from the maternal genital tract during delivery $(86 \%){ }^{2}$ However, $60 \%$ to $80 \%$ of the mothers have no medical history of contact with a partner with genital HSV and presented no signs or symptoms of genital her- pes during delivery. ${ }^{3}$ Infections by genital herpes are normally caused by HSV-2. Therefore, the majority of neonatal infections are caused by this virus. ${ }^{4}$

Neonates born by normal delivery from mothers that contract a primary genital infection present an attack rate estimated at $50 \%$, while the risk for NBs from mothers who presented a recurring infection is approximately $3 \% .^{5}$ There are many foreseeable reasons for a low neonatal incidence after recurring HSV infections. The NBs born from mothers that contracted a recurring infection caused by HSV most likely have antibodies acquired via transplacental infection, which would work as an immunoprophylaxis. ${ }^{2}$ In the recurring infections, the uterus is less frequently in- 


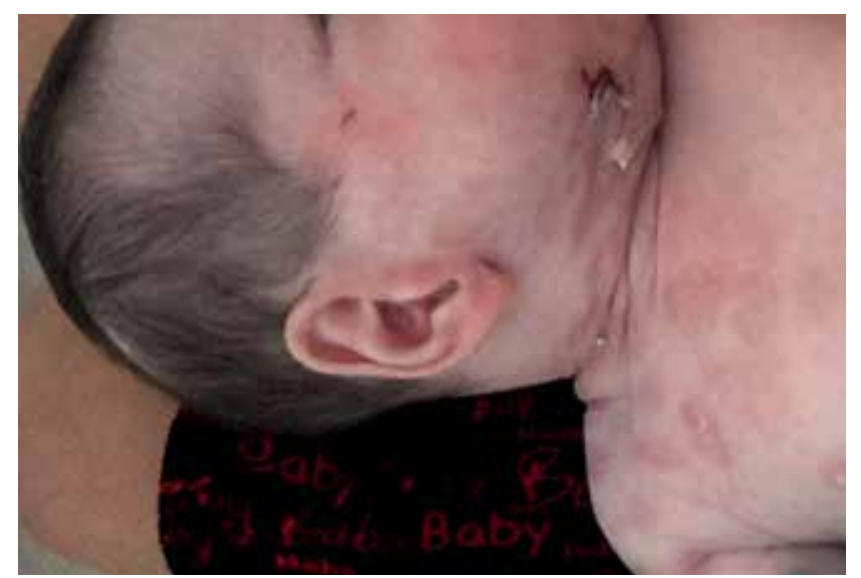

FiguRE 3: Lesional aspect after ten days of treatment with acyclovir

volved, and viral shedding occurs for a shorter time and to a lesser degree. ${ }^{2}$ Premature birth is also associated with HSV infection. ${ }^{6}$

The cutaneous findings are the first visible signs in approximately two thirds of the NBs infected with HSV. ${ }^{7}$ NBs that acquire the virus during normal delivery generally present symptoms six days to three weeks after birth, although, in some cases, the lesions can already be observed in the first day after birth, as seen in our case report. ${ }^{8}$

Neonatal herpes can spread quickly and involve the central nervous system and/or multiple internal organs. The neonatal condition can deteriorate quickly; therefore, an immediate and precise diagnosis is highly desirable. In this sense, the cytological exam (Tzanck test) of material obtained form the base of the vesicles, becomes extremely important, as it can reveal giant multinucleated epithelial cells.

Cytology is a simple, quick, reliable, and inexpensive diagnostic method that has been used for the diagnosis of various infectious and non-infectious cutaneous diseases. This method is rarely used for diagnostic purposes in dermatology, despite the quick and reliable results that it yields. ${ }^{9}$ It may be applied to a broad spectrum of dermatoses, including genodermatosis (Hailey-Hailey disease), infection (herpes infection, especially molluscum contagiosum and leishmaniasis), immunological disorders (pemphigus), and tumors (basal cell and squamous cell carcinomas, Paget's disease, erythroplasia of Queyrat, among others). ${ }^{9}$

The early treatment with high doses of acyclovir can drastically improve both short and long-term

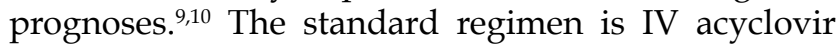
$(30 \mathrm{mg} / \mathrm{kg} /$ day) every 8 hours, for 3 weeks. However, the best neurological prognosis appears to be related to higher doses, with $60 \mathrm{mg} / \mathrm{kg} /$ day representing the most commonly recommended dose ${ }^{7}$

It can therefore be concluded that the NB in the present case report acquired the infection during his/ her passage through the birth canal. However, there was no maternal medical records regarding genital herpes nor any medical report of genital lesions on the part of the medical team during delivery. This discarded the suspicion and early diagnosis of a herpetic infection, confirmed only after having conducted the cytological exam. Therefore, we hereby recommend that all NBs that present vesicles or blisters during the neonatal period be submitted to this procedure.]

\title{
REFERENCES
}

1. Araújo T, Schacner L. Benign vesicopustular eruptions in the neonate. An Bras Dermatol. 2006;81:359-66.

2. Kesson, AL. Management of Neonatal Herpes Simplex Virus Infection. Paediatr Drugs. 2001;3:81-90.

3. Whitley R, Arvin A. Herpes simplex virus infections. In: Klein JR, Klein J, editors. Infectious diseases of the fetus and newborn infant. Philadelphia: Saunders; 1995 p.354-76.

4. Corey L, Wald A. Maternal and neonatal herpes simplex virus infections. N Engl J Med. 2009;361:1376-85.

5. Brown ZA, Benedetti J, Ashley R, Burchett S, Selke S, Berry S, et al. Neonatal herpes simplex virus infection in relation to asymptomatic maternal infection at the time of labor. N Engl J Med. 1991;324:1247-52.

6. Whitley R, Arvin A, Prober C, Corey L, Burchett S, Plotkin S, et al. Predictors of morbidity and mortality in neonates with herpes simplex infection. N Engl J Med. 1991;324:450-4.

7. Kimberlin DW, Lin CY, Jacobs RF, Powell DA, Frenkel LM, Gruber WC, et al. Natural history of neonatal herpes simplex virus infections in the acyclovir era. Pediatrics. 2001;108:223-9.

8. Conlon JD, Drolet BA. Skin lesions in the neonate. Pediatr Clin North Am. 2004;51:863-88, vii-viii.

9. Ruocco E, Brunetti G, Del Vecchio M, Ruocco V. The practical use of cytology for diagnosis in dermatology. J Eur Acad Dermatol Venereol. 2011;25:125-9.

10. Shah SS, Aronson PL, Mohamad Z, Lorch SA. Delayed acyclovir therapy and death among neonates with herpes simplex virus infection. Pediatrics. 2011;128:1153-60.

\author{
MAILING ADDRESS: \\ Maraya de Jesus Semblano Bittencourt \\ Av. Generalíssimo Deodoro, 91 - Umarizal \\ 66055-240 - Belém - PA \\ Brazil \\ E-mail: marayabittencourt@hotmail.com
}

How to vite this article: Bittencourt MJS, Freitas LKM, Drago MG, Carvalho AH, Nascimento BAM. Cutaneous neonatal herpes simplex virus infection type 2: a case report. An Bras Dermatol. 2016;91(2):216-8. 